\title{
Analysing Data Mining Applications in Healthcare Sector
}

\author{
N.Priya, C.Anuradha, R.Kavitha, D.Vimala
}

\begin{abstract}
In this paper, we've focused to check a scope of systems, approaches and very surprising instruments and its effect on the medicinal services segment. The objective knowledge of information mining application is to demonstrate that information zone unit realities, numbers, or content which may be handled by a pc into information or data. the most purpose of data of knowledge of info mining application in social insurance frameworks is to build up an automatic tool for particular and diffusing pertinent medicinal services data. This paper means to make an inside and out examination report of different sorts of information preparing applications inside the medicinal services segment and to reduce the multifaceted nature of the investigation of the social insurance data exchanges. moreover exhibits a relative investigation of different information handling applications, strategies and very surprising techniques connected for separating information from data produced inside the human services exchange. At long last, the overarching information processing techniques with information handling calculations and its application apparatuses that zone unit a great deal of important for medicinal services administrations zone unit referenced completely.
\end{abstract}

\section{Keywords : Data Mining, Information Retrieval}

\section{INTRODUCTION}

The reason knowledge of data mining is to extricate accommodating data from massive databases or information distribution centers. information handling applications are utilized for business and logical sides [1]. This investigation in the primary talks about the information Mining applications inside the logical viewpoint. Logical information handling separates itself inside the feeling that the character of the datasets is regularly terribly completely not the same as antiquated market driven information preparing applications.

In this work, a close survey is apportioned on information preparing applications inside the tending segment, sorts of data utilized and subtleties of the information removed.

\section{Revised Manuscript Received on July 22, 2019.}

N.Priya, Department of Computer Science and Engineering, Bharath Institute of Higher Education and Research, Chennai. Email: priyabiher@gmail.com

C.Anuradha,Department of Computer Science and Engineering, Bharath Institute of Higher Education and Research, Chennai. Email: anuradha.ak23@gmail.com

R.Kavitha,Department of Computer Science and Engineering, Bharath Institute of Higher Education and Research, Chennai. Email: kavis_happy@yahoo.co.in

D.Vimala,Department of Computer Science and Engineering, Bharath Institute of Higher Education and Research, Chennai. Email: vimalamuthu3@gmail.com information handling calculations connected in tending exchange assume a noteworthy job in expectation and diagnosing of the infections. There ar an outsized scope of information mining applications are found inside the medicinal associated territories like Medical gadget exchange, Pharmaceutical exchange and Hospital Management. to search out the accommodating and concealed data from the information is that the reason behind the applying of learning mining. Prevalently information preparing known as data revelation from the data. The data revelation is $\mathrm{AN}$ intelligent technique, comprising by building up A comprehension of the applying space, picking and making a data set, preprocessing, data change. information handling has been utilized in a scope of utilizations like advancing, customer relationship the board, designing, and medications examination, proficient forecast, net mining and versatile and portable registering.

In medicinal services foundations release the reasonable information frameworks to supply solid reports with respect to alternative information in entirely cash and volume associated articulations. information preparing instruments to answer the inquiry that truly was a period overpowering and too confused to even think about resolving. They get ready databases for finding prophetic information. information handling undertakings ar Association Rule, Patterns, Classification and Prediction, Clustering. most run of the mill demonstrating destinations are grouping and forecast. the clarification that pulled in a decent arrangement of consideration in information innovation for the creation of accommodating information from massive collections is a result of the observation that we tend to are data well off anyway data poor. Some the example information preparing applications are:

- Developing models to find misleading telephone or Visa movement

- Predicting reasonable and poor deals outline.

- Predicting regardless of whether an assault is most likely going to repeat among those with inward organ unwellness. - recognizing factors that outcome in deformities in an exceedingly creating technique.

Extending the wellbeing inclusion to the same number of us as potential, and furnishing cash help to help those with lower wages buy inclusion [2]. Disposing of current wellbeing variations would diminish the prices related to the augmented unwellness trouble borne by bound populace teams. Health organization or tending organization is that the field in regards to initiative, the board, and organization of medical clinics, emergency clinic systems, and human services 


\section{Analysing Data Mining Applications In Healthcare Sector}

systems[1,3]. inside the tending part Government spends additional cash.

Proposal in draft NHP 2001 is convenient that State wellbeing consumptions be raised to seven-membered by 2015 and to eight of State spending plans thus [21].

Health cost in Asian nation at 6 June 1944 of GDP is among the absolute best dimensions measurable for creating nations.

Public expense on wellbeing in Asian nation has itself declined when easement from one. $3 \%$ of total national output in 1990 to zero.9\% in 1999. Focal spending assignments for wellbeing have stagnated at one.3\%ofthe complete Central spending plan. inside the States it's declined from $7.0 \%$ to $5.5 \%$ of the State wellbeing spending plan.

\section{LITERATURE SURVEY}

A literature survey might be a content composed by crucial purposes of current data together with substantive notice hypothetical and technique commitments to a chose subject. Writing surveys square measure secondary sources and don't report any new or unique trial work.

HianChyeKoh and Gerald Tan essentially talks about information handling and its applications with significant territories like Treatment viability, Management of consideration, Detection of extortion and misuse, customer relationship management[1].

JayanthiRanjan introduces anyway information preparing finds and concentrates accommodating examples of this hugeknowledge to seek out perceivable examples. This paper shows the adaptability of informationmining in up the standard of the decision making strategy in pharmaceutical organization business. problemswithin the pharmaceutical organization business square measure unfavorable responses to the drug [2].

K. Srinivas, B. Kavitha ranee and Dr. A. Goverdhan talks about basically look at the potential utilization of order fundamentally based information preparing procedures like Rule principally based, call tree, Naïve mathematician and Artificial Neural Network to the extensive volume of consideration learning. exploitationAssociate in Nursing age, sex, fundamental sign and blood glucose restorative profiles it will anticipate the likelihood of patients getting a heart disease[4].

ShwetaKharyadiscussed changed information handling approaches that are utilized for carcinoma assignment and visualization call tree is observed to be the best indicator with ninety three.62\% Accuracy on benchmark knowledgeset and conjointly on SEER information set[5].

Elias Lemuye referenced the AIDS is that the sickness brought about by HIV, that debilitates the body's framework till it willnow not battle the clear contaminations that practically all solid individuals' framework will stand up to. Apriori algorithmic program is utilized to discover affiliation rules. WEKA 3.6 is utilized on the grounds that the information preparing instrument to actualize the
Algorithms. The J48 classifier performs grouping with eighty one. $8 \%$ exactness in foreseeing the HIV status[6]

Arvind Sharma and P.C. Gupta discussedData mining will contribute with crucial edges to the bank area. J48 algorithmic program and maori hen device are utilized for the whole examination work. Order rules performed well inside the grouping of blood givers, whose precision rate achieved eighty nine.9\%[7-15].

\section{CASE STUDY}

This part, a near investigation of data mining applications in help area by totally different researchers given well. essentially information preparing devices territory unit acclimated anticipate the gainful outcomes from the data recorded on help issues[15-20]. totally unique information handling instruments territory unit accustomed predict the exactness level in various guide issues. amid this investigation, the ensuing rundown of restorative issues has been broke down and assessed. [21-25]

- cardiovascular illness

- Cancer

- HIV/AIDS

- Blood

- Brain Cancer

- T.B.

- diabetes

- urinary organ synthetic examination

- Dengue

- IVF

\section{RESULTS AND DISCUSSION}

In the Table one, the most imperative guide issues explicitly in infection aspect and examination results are shown. The maladies territory unit the premier basic issues in human. to examine the viability of the info mining applications for recognizable proof the disorder, the standard procedures of scientific/connected science applications likewise are given and looked at. Recorded eleven issues region unit taken for correlation with this work. [25-30]

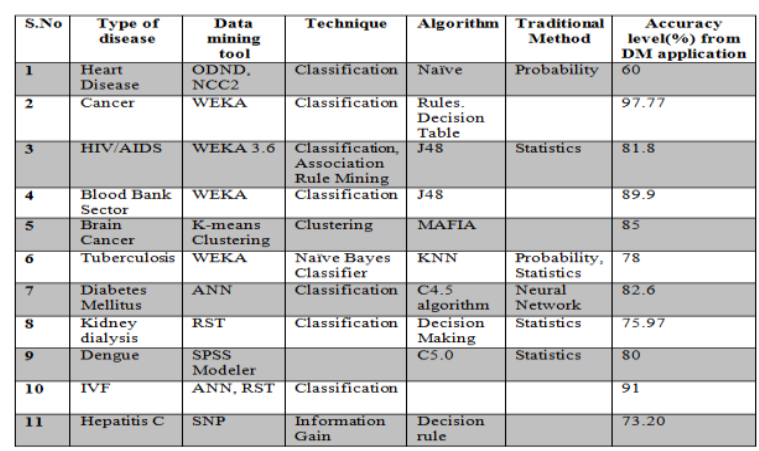

TABLE 1. Data Mining Applications in HealthCare

This paper intended to coordinate the different information handling application inside the medicinal services part to separate supportive information. The expectation of infections abuse information preparing applications might be a difficult assignment anyway it radically decreases the human exertion and will 
build the analytic precision.[31-35] Creating prudent information preparing instruments for AN application may decrease the esteem and time requirement as far as HR and experience. Investigating data from the medicinal data is such a hazard errand on the grounds that the data discovered region unit hollering, inapplicable and enormous as well. amid this circumstance, information handling devices are accessible convenient in investigating of knowledge of information of information $\}$ of the medicinal information and it's very eye catching. it's determined from this examination that a blend of very one information handling methods than one strategy for assignment or anticipating maladies in human services segment may yield awe inspiring outcomes. The correlation think about demonstrates the eye catching outcomes that information preparing procedures on the whole the social insurance applications gives an a ton of encouraging dimension of precision like ninety seven.77\% for malignant growth forecast and around seventy you deal with assessing the achievement rate of IVF treatment.[36-41]

\section{CONCLUSION}

To accomplish the 2050 imperativeness viability similarly as economical power source targets and besides for the future sharp structures, convincing use of adroit metering development is crucial. Ordinary essentialness use is a flat out need for a greater social occasion of associations, areas and open relationship because of the expansion in importance of the imperativeness costs and biological issues. Therefore authentic information about their usage is required by them nearby and its assignment between different activities. A total picture of their imperativeness use, potential for venture assets, close by costs can be given to them by quick meter data examination, engaging fruitful essentialness the officials. Clever meter sends imperativeness usage data at little breaks realizing making colossal data. Time and limit are two huge components that impact a ton on structure any application.

\section{REFERENCES}

[1] Kumaravel A., Rangarajan K.,Algorithm for automaton specification for exploring dynamic labyrinths,Indian Journal of Science and Technology,V-6,I-SUPPL5,PP-4554-4559,Y-2013

[2] P. Kavitha, S. Prabakaran “A Novel Hybrid Segmentation Method with Particle Swarm Optimization and Fuzzy C-Mean Based On Partitioning the Image for Detecting Lung Cancer" International Journal of Engineering and Advanced Technology (IJEAT) ISSN: 2249-8958, Volume-8 Issue-5, June 2019

[3] Kumaravel A., Meetei O.N.,An application of non-uniform cellular automata for efficient cryptography,2013 IEEE Conference on Information and Communication Technologies, ICT 2013,V-,I-,PP-1200-1205,Y-2013

[4] Kumarave A., Rangarajan K.,Routing alogrithm over semi-regular tessellations,2013 IEEE Conference on Information and Communication Technologies, ICT 2013,V-,I-,PP-1180-1184,Y-2013

[5] P. Kavitha, S. Prabakaran "Designing a Feature Vector for Statistical Texture Analysis of Brain Tumor" International Journal of Engineering and Advanced Technology (IJEAT) ISSN: 2249-8958, Volume-8 Issue-5, June 2019

[6] Dutta P., Kumaravel A.,A novel approach to trust based identification of leaders in social networks,Indian Journal of Science and Technology,V-9,I-10,PP--,Y-2016

[7] Kumaravel A., Dutta P.,Application of Pca for context selection for collaborative filtering,Middle - East Journal of Scientific Research,V-20,I-1,PP-88-93,Y-2014
[8] Kumaravel A., Rangarajan K.,Constructing an automaton for exploring dynamic labyrinths,2012 International Conference on Radar, Communication and Computing, ICRCC 2012,V-,I-,PP-161-165,Y-2012

[9] P. Kavitha, S. Prabakaran "Adaptive Bilateral Filter for Multi-Resolution in Brain Tumor Recognition" International Journal of Innovative Technology and Exploring Engineering (IJITEE) ISSN: 2278-3075, Volume-8 Issue-8 June, 2019

[10] Kumaravel A.,Comparison of two multi-classification approaches for detecting network attacks, World Applied Sciences Journal,V-27,I-11,PP-1461-1465,Y-2013

[11] Tariq J., Kumaravel A.,Construction of cellular automata over hexagonal and triangular tessellations for path planning of multi-robots,2016 IEEE International Conference on Computational Intelligence and Computing Research, ICCIC 2016,V-,I-,PP--,Y-2017

[12] Sudha M., Kumaravel A.,Analysis and measurement of wave guides using poisson method,Indonesian Journal of Electrical Engineering and Computer Science,V-8,I-2,PP-546-548,Y-2017

[13] Ayyappan G., Nalini C., Kumaravel A.,Various approaches of knowledge transfer in academic social network,International Journal of Engineering and Technology,V-,I-,PP-2791-2794,Y-2017

[14] Kaliyamurthie, K.P., Sivaraman, K., Ramesh, S. Imposing patient data privacy in wireless medical sensor networks through homomorphic cryptosystems 2016, Journal of Chemical and Pharmaceutical Sciences92.

[15] Kaliyamurthie, K.P., Balasubramanian, P.C. An approach to multi secure to historical malformed documents using integer ripple transfiguration 2016 Journal of Chemical and Pharmaceutical Sciences92.

[16] A.Sangeetha,C.Nalini,"Semantic Ranking based on keywords extractions in the web", International Journal of Engineering \& Technology, 7 (2.6) (2018) 290-292

[17] S.V.GayathiriDevi,C.Nalini,N.Kumar,"An efficient software verification using multi-layered software verification tool "International Journal of Engineering \& Technology, 7(2.21)2018 454-457

[18] C.Nalini,ShwtambariKharabe,"A Comparative Study On Different Techniques Used For Finger - Vein Authentication", International Journal Of Pure And Applied Mathematics, Volume 116 No. 8 2017, 327-333, Issn: 1314-3395

[19] M.S. Vivekanandan and Dr. C. Rajabhushanam, "Enabling Privacy Protection and Content Assurance in Geo-Social Networks", International Journal of Innovative Research in Management, Engineering and Technology, Vol 3, Issue 4, pp. 49-55, April 2018.

[20] Dr. C. Rajabhushanam, V. Karthik, and G. Vivek, "Elasticity in Cloud Computing", International Journal of Innovative Research in Management, Engineering and Technology, Vol 3, Issue 4, pp. 104-111, April 2018.

[21] K. Rangaswamy and Dr. C. Rajabhushanamc, "CCN-Based Congestion Control Mechanism In Dynamic Networks", International Journal of Innovative Research in Management, Engineering and Technology, Vol 3, Issue 4, pp. 117-119, April 2018.

[22] Kavitha, R., Nedunchelian, R., "Domain-specific Search engine optimization using healthcare ontology and a neural network backpropagation approach", 2017, Research Journal of Biotechnology, Special Issue 2:157-166

[23] Kavitha, G., Kavitha, R., "An analysis to improve throughput of high-power hubs in mobile ad hoc network" , 2016, Journal of Chemical and Pharmaceutical Sciences, Vol-9, Issue-2: 361-363

[24] Kavitha, G., Kavitha, R., "Dipping interference to supplement throughput in MANET" , 2016, Journal of Chemical and Pharmaceutical Sciences, Vol-9, Issue-2: 357-360

[25] Michael, G., Chandrasekar, A.,'Leader election based malicious detection and response system in MANET using mechanism design approach", Journal of Chemical and Pharmaceutical Sciences(JCPS) Volume 9 Issue 2, April - June 2016

[26] Michael, G., Chandrasekar, A.,"Modeling of detection of camouflaging worm using epidemic dynamic model and power spectral density", Journal of Chemical and Pharmaceutical Sciences(JCPS) Volume 9 Issue 2, April - June 2016

[27] Pothumani, S., Sriram, M., Sridhar, J., Arul Selvan, G., Secure mobile agents communication on intranet,Journal of Chemical and Pharmaceutical Sciences, volume 9, Issue 3, Pg No S32-S35, 2016

[28] Pothumani, S., Sriram, M., Sridhar, Various schemes for database encryption-a survey, 
Journal of Chemical and Pharmaceutical Sciences, volume 9, Issue 3, Pg NoS103-S106, 2016

[29] Pothumani, S., Sriram, M., Sridhar, A novel economic framework for cloud and grid computing, Journal of Chemical and Pharmaceutical Sciences, volume 9, Issue 3, Pg No S29-S31, 2016

[30] Priya, N., Sridhar, J., Sriram, M. "Ecommerce Transaction Security Challenges and Prevention Methods- New Approach" 2016 ,Journal of Chemical and Pharmaceutical Sciences, JCPS Volume 9 Issue 3.page no:S66-S68 .

[31] Priya, N.,Sridhar,J.,Sriram, M."Vehicular cloud computing security issues and solutions" Journal of Chemical and Pharmaceutical Sciences(JCPS) Volume 9 Issue 2, April - June 2016

[32] Priya, N., Sridhar, J., Sriram, M. "Mobile large data storage security in cloud computing environment-a new approach" JCPS Volume 9 Issue 2. April - June 2016

[33] Anuradha.C, Khanna.V, "Improving network performance and security in WSN using decentralized hypothesis testing "Journal of Chemical and Pharmaceutical Sciences(JCPS) Volume 9 Issue 2, April - June 2016.

[34] Anuradha.C, Khanna.V, "A novel gsm based control for e-devices" Journal of Chemical and Pharmaceutical Sciences(JCPS) Volume 9 Issue 2, April - June 2016.

[35] Anuradha.C, Khanna.V, "Secured privacy preserving sharing and data integration in mobile web environments " Journal of Chemical and Pharmaceutical Sciences(JCPS) Volume 9 Issue 2, April - June 2016.

[36] Sundarraj, B., Kaliyamurthie, K.P. Social network analysis for decisive the ultimate classification from the ensemble to boost accuracy rates 2016 International Journal of Pharmacy and Technology

[37] Sundarraj, B., Kaliyamurthie, K.P. A content-based spam filtering approach victimisation artificial neural networks 2016 International Journal of Pharmacy and Technology83.

[38] Sundarraj, B., Kaliyamurthie, K.P. Remote sensing imaging for satellite image segmentation 2016 International Journal of Pharmacy and Technology8 3 .

[39] Sivaraman, K., Senthil, M. Intuitive driver proxy control using artificial intelligence 2016 International Journal of Pharmacy and Technology84.

[40] Sivaraman, K., Kaliyamurthie, K.P. Cloud computing in mobile technology 2016 Journal of Chemical and Pharmaceutical Sciences92.

[41] Sivaraman, K., Khanna, V. Implementation of an extension for browser to detect vulnerable elements on web pages and avoid click jacking 2016 Journal of Chemical and Pharmaceutical Sciences92.

\section{AUTHORS PROFILE}

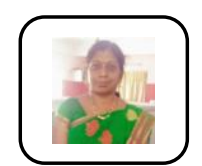

N.Priya Assistant Professor, Department of Computer Science \& Engineering, Bharath Institute of Higher Education and Research, Chennai, India

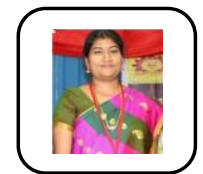

C.Anuradha Assistant Professor, Department of Computer Science \& Engineering, Bharath Institute of Higher Education and Research, Chennai, India

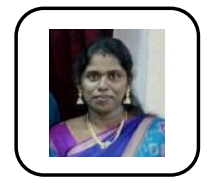

R.Kavitha Professor, Department of Computer Science \& Engineering, Bharath Institute of Higher Education and Research, Chennai, India

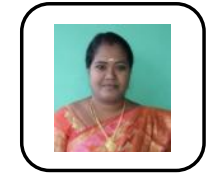

D.Vimala Assistant Professor, Department of Computer Science \& Engineering, Bharath Institute of Higher Education and Research, Chennai, India 